Original Research Paper

\title{
Potential of Forest Bird Diversity and Abundance in Tretes Waterfall, Wonosalam as an Avitourism Location
}

\author{
Muhammad Zahrudin Afnan ${ }^{1 *}$, Monica Salma Fitriandini' ${ }^{1}$, Mahendra Ekalukmana \\ Firmansyah $^{1}$ \\ ${ }^{1}$ Jurusan Biologi, Fakultas Matematika dan Ilmu Pengetahuan Alam, Universitas Negeri Surabaya, \\ Surabaya, Indonesia
}

\begin{abstract}
Article History
Received : November $25^{\text {th }}, 2021$

Revised : December 05 ${ }^{\text {th }}, 2021$

Accepted : December $25^{\text {th }}, 2021$

Published : January $10^{\text {th }}, 2022$

*Corresponding Author:

Muhammad Zahrudin Afnan, Universitas Negeri Surabaya,

Surabaya, Indonesia;

Email:

muhammadzahrudin.19001@mhs .unesa.ac.id
\end{abstract}

\begin{abstract}
Tretes Waterfall is an avitourism area because it is located in the Raden Soerjo Grand Forest Park area. The diversity of bird species is very abundant there, especially forest birds. The diversity and abundance of birds are influenced by the condition of the forest which is still beautiful and the availability of various types of trees and other living things as a source of food for a bird. The purpose of this research To analyze the potential diversity and abundance of forest birds in Tretes waterfall, Wonosalam as an avitourism location and Analyzing the carrying capacity of management as Tretes Waterfall, Wonosalam, an avitourism location. The study was carried out from June to September 2021. The method used is the IPA (Index Point of Abudance) method, namely bird data collection is carried out at a certain time where there are 4 observation points and the rapid assessment method. The species of birds found in Tretes Waterfall, Wonosalam were 45 species with the abundance value of bird species at the observation point of residential residents categorized as general. While the abundance of bird species at the observation points of post 1 , post 2 , and waterfalls is in the frequent category $(2.1-10,0)$. Tretes Waterfall has the potential to be developed as an avitourism area. More in-depth research can be carried out to determine the spatial and temporal distribution of birds in Tretes Waterfall so that avitourism is easier to develop.
\end{abstract}

Keywords: Avitourism, Forest Birds, Tretes Waterfalls, Diversity, Abundance

\section{Pendahuluan}

Avitourism merupakan suatu pariwisata bernuansa alam yang berfokus pada pengamatan burung yang ada di alam liar. Pengamatan burung saat ini menjadi hobi yang sudah tidak asing serta banyak peminatnya, serta memiliki nilai pasar dan kebermanfatannya yang dipercaya. Hal tersebut sesuai definisi avitourism yang disampaikan oleh Cordell \& Herbet (2002); Sekercioglu (2002); US Fish and Wildlife Service (2001; 2007). Pariwisata dimanfaatkan sebagai media untuk melakukan kegiatan konservasi dan pembangunan, utamanya dilakukan oleh negara-negara berpenghasilan rendah dan menengah di suatu pedesaan, serta sedang gencar digaungkan selama beberapa dekade terakhir. Sejalan dengan apa yang disampaikan oleh Hvengaard \& Dearden (1998); Naidoo \& Adamowicz (2005a, b). Solusi dalam mengatasi pendeknya jarak interaksi antara manusia dengan burung yaitu dengan mengembangkan pariwisata berbasis ekowisata avitourism. Manfaat ekowisata ada 2 yaitu secara ekonomis dan pendidikan. Dapat menciptakan lapangan pekerjaan adalah manfaat secara ekonomis, sedangkan secara pendidikan dapat memberikan manfaat konservasi serta pembangunan manusia (Briggs, 2011). Apabila diketahui data keanekaragaman burung di suatu kawasan maka kawasan tersebut layak dijadikan sebagai tempat pengembangan avitourism. Kurangnya eksplorasi berkaitan dengan data keanekaragaman burung hutan di Air Terjun Tretes masih kurang optimal hal tersebut merupakan suatu kekurangan. Oleh karena itu, tujuan dilaksanakannya penelitian 
ini yaitu menganalisis keanekaragaman burung sebagai potensi untuk dijadikan kawasan avitourism di objek wisata Air Terjun Tretes, Wonosalam.

Wonosalam terkenal dengan wisata alamnya dengan pemandangan yang indah, salah satunya Air Terjun Tretes. Air Terjun Tretes berada di kawasan konservasi Tahura Raden Soerjo yang merupaakan salah satu tempat bernuansa avitourism, kawasan tersebut masuk wilayah administratif desa Galeng Dowo Kecamatan Wonosalam, Kabupaten Jombang pada $7^{\circ} 46^{\prime} 20,867^{\prime}$ - $7^{\circ} 46^{\prime} 41,543$ LS dan $112^{\circ} 23^{\prime} 39,485^{\prime \prime}-112^{\circ} 24^{\prime} 23,804$ " BT. Air terjun tersebut sudah sangat populer di kalangan masyarakat, yang memiliki ketinggian $\pm 170 \mathrm{~m}$ menjadikannya sebagai salah satu air terjun paling tinggi se-Jawa Timur. Selain itu Air terjun ini termasuk bagian dari hulu sungai Sumber Watu Bonakah, yang terletak di Gunung Jurung Guah, terletak pada ketinggian $1.172 \mathrm{mdpl}$.

Avifauna menurut Wisnubudi (2009) merupakan suatu satwa yang dapat mudah dijumpai di berbagai tempat, peranannya sangat penting sebagai bentuk kekayaan satwa di Indonesia. Terdapat keanekaragaman jenis dan mempunyai ciri khas keindahan masingmasing. Sedangkan definisi Avifauna menurut Syafrudin (2011) adalah salah satu satwa yang biasanya dapat dijumpai hampir di berbagai tempat, tetapi kehidupannya dipengaruhi oleh habitat yang mendukung, seperti tersedianya kebutuhan untuk makan serta aman dari predator dan segala macam gangguan. Avifauna yang menjadi fokus penelitian adalah burung hutan, dikutip dari Natural Resources Conservation Service (2014) definisi burung hutan yaitu burung yang berkicau di hutan, bermigrasi serta berkembang biak di hutan yang luas. Negara dengan kekayaan burung tertinggi nomor empat di dunia adalah Indonesia, posisi keempat setelah Kolombia, Brazil, dan Peru (Sukmatoro, 2007). Dikutip dari Burung Indonesia (2018) biodiversitas burung diIndonesia ada sebanyak 1.771 jenis dimana 513 jenis adalah burung endemik. Pulau Jawa memiliki 507 spesies burung dengan 56 spesies adalah endemik dan 32 spesies adalah burung endemik wilayah (Sukmatoro, 2007). Menurut Birdlife International (2004) terdapat 40 titik Important Bird Area di Pulau Jawa. Terkhusus
Provinsi Jawa Timur terdapat enam titik dan salah satunya adalah Gunung Anjasmoro. Seperti pada umumnya di Pulau Jawa, di Gunung Anjasmoro pun burung mengalami ancaman berupa kerusakan habitatnya, adanya penggunaan pestisida secara berlebih, dan banyak burung yang ditangkapn untuk dikonsumsi maupun dipelihara. (Diamond, 1987).

Air Terjun Tretes merupakan daerah avitourism karena letaknya pada kawasan Taman Hutan Raya Raden Soerjo. Keanekaragaman jenis burung sangat melimpah disana, utamanya burung hutan. Keanekaragaman dan kemelimpahan burung dipengaruhi oleh kondisi hutan yang masih asri serta adanya ketersediaan berbagai jenis pohon dan makhluk hidup lainnya sebagai sumber makanan suatu burung. Dalam penelitian diperlukannya banyak referensi melalui seseorang ahli maupun data hasil penelitian yang lalu dan dipublikasikan dalam bentuk artikel maupun jurnal. Hasil penelitian yang telah lalu dijadikan sebagai wawasan pengetahuan dan target yang harus dicapai dalam penelitian lanjutan.

Definisi vegetasi menurut Maarel (2005) adalah suatu tatana yang didalamnya terdapat sekelompok besar tumbuhan yang tumbuh dan menghuni suatu wilayah. Peranan penting vegetasi di ekosistem yang didalamnya banyak proses berlangsung diantaranya diungkapkan oleh Smith, et .al (2000) antara lain: (a) penyimpanan dan daur nutrisi; (b) penyimpanan karbon; (c) purifikasi air; serta (d) keseimbangan dan penyebaran berbagai komponen penting penyusun ekosistem yaitu detrivor, polinator, parasit, dan predator. Pada kawasan Tahura Raden Soeryo Vegetasi hutannya sangatlah beragam sehingga memungkinkan terjadinya keseimbangan ekosistem serta masih ditemukannya keanekaragaman dan kemelimpahan burung hutan.

Menurut Soemarwoto (2001), hakekat daya dukung lingkungan yaitu daya dukung lingkungan alamiah, dimana berdasarkan biomas tumbuhan dan hewan yang dapat ditangkap dan dikumpulkan per satuan luas dan waktu di daerah itu. Daya dukung dimana jumlah populasi manusia yang tidak dibatasi dengan ekosistem dan tidak menimbulkan 
kerusakan ekosistem itu sendiri. Luas lahan dan vegetasi berupa jumlah pohon beserta jenisnya juga menjadi daya dukung terbentuknya keanekaragaman dan kemelimpahan burung hutan. Indonesia sangatlah memiliki banyak jenis burung baik endemik maupun endemik, karena potensi tersebut perlunya penelitian lebih lanjut untuk menganalisis keanekaragaman dan kemelimpahan burung hutan di suatu wilayah salah satunya untuk melestarikannya serta menjadikan suatu wilayah khususnya daerah air terjun tretes sebagai avitourism.

Jadi dengan banyak referensi artikel, jurnal maupun sejenisnya dapat menambah wawasan pengetahuan penulis dan untuk memperkuat hasil penelitian selain data penelitian, supaya dapat menghasilkan data penelitian yang berkualitas, dapat dibuktikan kebenarannya dan bermanfaat bagi masyarakat maupun penelitian lanjutan.

\section{Bahan dan Metode}

\section{Waktu dan Tempat}

Air Terjun Tretes merupakan sasaran wisata yang dijadikan objek penelitian ini. Air Terjun Tretes Merupakan air terjun tertinggi di Jawa Timur dengan ketinggian $\pm 170 \mathrm{~m}$, terletak di kawasan Tahura Raden Soerjo, yang secara administratif berada di Desa Galeng Dowo Kec. Wonosalam, Kabupaten Jombang pada $7^{\circ} 46^{\prime}$ 20,867' - $7^{\circ} 46^{\prime} 41,543 \mathrm{LS}$ dan $112^{\circ} 23^{\prime} 39,485^{\prime}$ ' $-112^{\circ} 24^{\prime} 23,804^{\prime \prime}$ BT. Air terjun ini merupakan hulu sungai Sumber Watu Bonakah, memiliki panorama alam indah yang berada di Gunung Jurung Guah. Lokasi Air Terjun ada di ketinggian 1.172 mdpl. Pelaksanaannya di bulan Juni sampai September 2021.

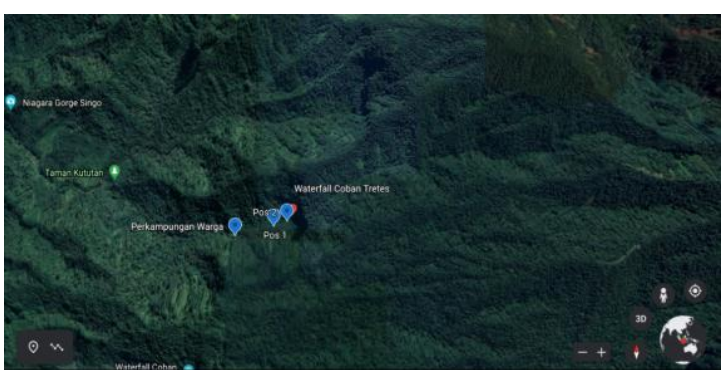

Gambar 1. Peta Air Terjun Tretes, Wonosalam

\section{Alat dan Bahan.}

Alat dan bahan yang digunakan meliputi alat tulis, binokuler nikon action $(16 \times 50 \mathrm{~mm})$, kamera prosummer nikon coolpix P900, kompas, hand counter, tabel pengamatan, GPS dan buku panduan identifikasi burung Mackinnon serta Atlas Burung Indonesia (2010). Objek penelitiannya yaitu berbagai jenis burung yang ditemukan beserta vegetasi yang dimanfaatkan oleh burung dalam kehidupannya.

\section{Prosedur Kerja}

Penggunaan metode IPA (Index Point of Abudance) yaitu metode dimana data burung yang diambil dilakukan di tempat dengan waktu tertentu (Bibby, 2000). Data burung diambil pada pukul 06.00-10.00 WIB dan 13.00-17.00 WIB. Tempat pengamatan di perkampungan desa Galeng Dowo Kecamatan wonosalam kemudian jalan antara loket dengan parkir sepeda motor dijadikan pos 1 dan jarak antara loket ke tempat istirahat menjadi pos 2 dan yang terakhir adalah Air Terjun Tretes. Durasi pengamatan yaitu 15 menit di setiap titik. Data penelitian berupa jenis burung dan jumlah individu. Penggunaan metode rapid assessment dalam pengamatan vegetasi. Teknis metode ini dengan cara berjalan mengikuti jalur pengamatan burung yang sudah ditentukan sebelumnya dan pengamatan tumbuhan yang menyusun vegetasi habitat mulai dari bagian belakang, depan, samping, dan kanan (Bismark, 2011).

Pelaksanaan pengamatan akan berkonsentrasi pada suatu titik yang diduga sebagai tempat dengan peluang perjumpaan burung tinggi. Pengamatan dapat dilakukan pada tempat yang tersembunyi sehingga aktivitas burung tidak terganggu. Keberadaan burung dapat diketahui melalui perjumpaan dan suara. Data yang dicatat yaitu spesies burung, jumlah individu spesies, dan aktivitas burung pada saat pengamatan baik yang dilihat langsung oleh pengamat maupun yang didengar. Data sekunder meliputi studi literatur yang mendukung penelitian, seperti: Karakteristik lokasi penelitian mulai dari keadaan fisik lokasi penelitian sampai data pendukung lainnya yang sesuai dengan topik penelitian. Kondisi umum areal pengamatan diamati dengan metode rapid assessment yang merupakan modifikasi dari habitat assessment bertujuan mendapatkan gambaran secara umum tipe vegetasi di tempat ditemukannya keberadaan burung (Bismark, 2011). Data yang dicatat meliputi jenis burung dan jumlahnya serta posisi burung pada strata tajuk. Kondisi habitat dapat diketahui dengan melakukan analisis vegetasi dan 
pembuatan profil habitat. Parameter vegetasi yang dikaji meliputi jenis dan jumlah vegetasi.

\section{Analisis Data}

Nama ilmiah, nama Indonesia, dan famili burung berdasarkan apa yang ada pada buku Mackinnon, Birds of the Indonesian Archipelago: Greater Sundas and Wallacea, dan Handbook of the Birds of the World and BirdLife International. Menganalisis secara deskriptif kualitatifkuantitatif potensi avitourism berdasarkan endemisitas, status konservasi dan keanekaragaman burung (Puhakka et al, 2011). Selain itu juga burung yang memiliki suara merdu, serta warna yang menarik (Garnet et al, 2018), burung yang memiliki kicauan indah mengacu pada KLHK (2019) serta burung jenis raptor (Aditya et al, 2019) berdasarkan Mackinnon. Bersamaan dengan hal tersebut juga terdapat atribut kawasan avitourism (Conradie, 2015), dan keanekaragaman jenis tipe pakan burung/feeding guild yang mengacu pada Mackinnon. Endemisitas mengacu pada Mackinnon dan Handbook of the Birds of the World and BirdLife International. Status konservasi mengacu pada IUCN Redlist status perdagangan internasional CITES (2015) Appendices I, II and III dan Peraturan Menteri Lingkungan Hidup dan kehutanan Republik Indonesia Nomor 106 tahun 2018 tentang Jenis Tumbuhan dan Satwa Yang Dilindungi. Keanekaragaman burung dianalisis menggunakan indeks keanekaragaman ShannonWiener, indeks kelimpahan relatif dan indeks kekayaan jenis serta analisis vegetasi.

\section{Rumus indeks keanekaragaman Shannow Wienner} (H') (Odum, 1991):

$$
\begin{aligned}
& H^{\prime}=-H 1=-a ̊[(n i / N) / \operatorname{Ln}(n i / N)] \\
& \text { pi }=(n i / N) \\
& \text { Keterangan: } \\
& \text { Pi : Jumlah proporsi kelimpahan satwa }
\end{aligned}
$$
spesies $\mathrm{i}$

H': Indeks keanekaragaman ShannonWienner

ni : Jumlah individu jenis ke-i

$\mathrm{N}$ : Jumlah individu seluruh jenis

Ln : Logaritma natural
Kriteria indeks Shannon-Wienner (H') (Odum, 1991), sebagai berikut:

$\mathrm{H}^{\prime}<1$ : keanekaragaman rendah

$1<\mathrm{H}^{\prime}<3$ : keanekaragaman sedang

$\mathrm{H}^{\prime}>3$ : keanekaragaman tinggi

\section{Rumus Indeks Kemelimpahan Relatif}

Kelimpahan biasanya digunakan dalam memperkirakan kepadatan setiap jenis burung dengan jenis lain di suatu kawasan per satuan waktu dengan rumus sebagai berikut (Bibby, 2000):

$\mathrm{KR}=\frac{\text { Jumlah } \text { individu jenis burung }}{\ln \text { N jumlah } \text { jam pengamatan }} \times 10$

Kriteria kelimpahan berdasarkan Biological surveys and conservation priorities in eastern Paraguy. Cambridge dalam buku Teknikteknik lapangan survei burung. Bogor yaitu:

Tabel 1. Kriteria Kemelimpahan

\begin{tabular}{ccc}
\hline $\begin{array}{c}\text { Kategori } \\
\text { Kemelimpaha } \\
\mathrm{n}\end{array}$ & $\begin{array}{c}\text { Nilai } \\
\text { Kemelim } \\
\text { pahan }\end{array}$ & $\begin{array}{c}\text { Skala } \\
\text { Ukuran }\end{array}$ \\
\hline$<0,1$ & 1 & Jarang \\
$0,1-2,0$ & 2 & Tidak \\
$2,1-10,0$ & 3 & Umum \\
$10,1-40,0$ & 4 & Uering \\
$>40,0$ & 5 & Melimpah \\
\hline
\end{tabular}

Rumus Indeks Kekayaan Jenis

Kekayaan jenis dihitung menggunakan indeks kekayaan jenis (Margalef Clifford \& Stepehenson 1975) dengan rumus:

$\operatorname{Dmg}=\frac{(S-1)}{\ln N}$

Keterangan:

DMG : Indeks kekayaan jenis Margalef

$\mathrm{S} \quad$ : Jumlah spesies

$\mathrm{N}$ : Jumlah total individu pada seluruh spesies

\section{Hasil dan Pembahasan}

Keanekaragaman, Kemelimpahan dan

Kekayaan Burung 


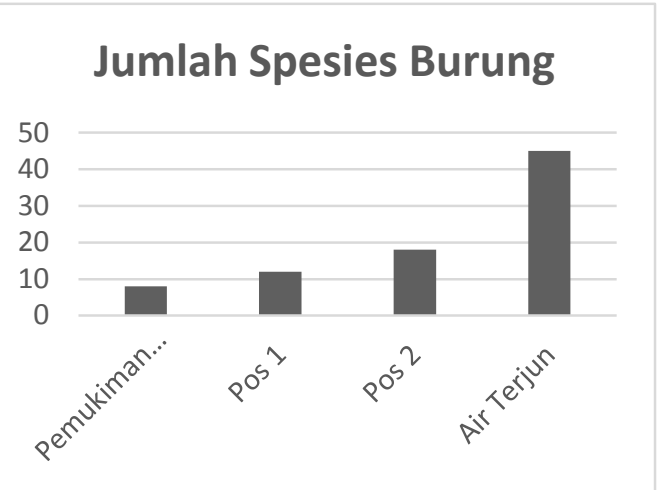

Gambar 2. Grafik Jumlah Spesies Burung

Pengamatan pada Air Terjun Tretes mendapatkan hasil yaitu terdapat kemelimpahan tertinggi dimana ada 159 individu dengan 45 jenis, diikuti oleh Pos 2108 individu dengan 18 Jenis , Pos 198 individu dengan 12 jenis, kemudian di Pemukiman Warga 88 individu dengan 8 jenis.

Burung yang didapatkan sebanyak 45 spesies yang tersebar di 4 titik pengamatan (pemukiman warga, pos 1, pos 2, dan air terjun). Berdasarkan CITES (2015), kriteria indeks keanekaragaman Shannon-Wienner (H') dapat dikategorikan menjadi 3 yaitu: (1) $\mathrm{H}^{\prime}<1$ : keanekaragaman tingkat rendah, $1<\mathrm{H}^{\prime} \quad 3$ : keanekaragaman tingkat sedang dan $\mathrm{H}^{\prime}>3$ : keanekaragaman tingkat tinggi. Tingkat keanekaragaman burung di Kawasan Air Terjun Tretes Wonosalam termasuk kategori sedang hingga tinggi. Berdasarkan hasil perhitungan Shannon-Wienner didapatkan hasil 3 titik pengamatan yaitu pemukiman warga, pos 1 dan pos 2 memiliki nilai indeks keanekaragaman yang sedang yaitu masing-masing sebesar 1,$696 ; 2,15$ ; dan 2,28. Sedangkan indeks tertinggi didapatkan pada titik pengamatan air terjun yaitu sebesar 3,204.

Jumlah jenis burung yang ditemukan di setiap titik berbeda. Kondisi habitat sangat mempengaruhi keanekaragaman burung. Habitat yang baik sangat mendukung kehidupan burung guna mendapatkan sumber makanan dan tempat perlindungan (Rumanasari, et al, 2017). Kondisi habitat yang terdapat berbagai spesies dan interaksi antar komponen fisik menjadikan habitat aman dan nyaman untuk burung (Riefani, 2019).
Tabel 2. Keanekaragaman dan Kemelimpahan

\begin{tabular}{lllll}
\hline Titik & $\begin{array}{l}\text { Jumlah } \\
\text { Spesies }\end{array}$ & $\begin{array}{l}\text { Jumlah } \\
\text { Individu }\end{array}$ & ln N & Margalef \\
\hline Pemukiman & 8 & 88 & 4,477 & 1,563 \\
Warga & & 98 & 4,585 & 2,399 \\
Pos I & 12 & 98 & 4,682 & 3,631 \\
Pos II & 18 & 108 & 5,069 & 8,680 \\
Air Terjun & 45 & 159 & & \\
\hline
\end{tabular}

Berdasarkan tabel tersebut dapat dilihat bahwa keanekaragam pada titik pengamatan air terjun tinggi yaitu ditemukan sebanyak 45 spesies burung. Hal tersebut sangat dipengaruhi oleh kondisi vegetasi dan habitat. Dimana pada titik air terjun terdapat sumber mata air dan berbagai macam jenis pohon. Nilai kelimpahan jenis burung pada titik pengamatan pemukiman warga dikategorikan umum. Sedangkan kelimpahan jenis burung pada titik pengamatan pos 1 , pos 2 dan air terjun termasuk kategori sering $(2,1-10,0)$.

\section{Nilai Kekayaan Jenis}

Tabel 3. Nilai Kekayaan Jenis

\begin{tabular}{llll}
\hline Titik & $\mathrm{H}^{\prime}$ & Evennes & $\mathrm{e}^{\prime}$ \\
\hline Pemukiman & 1,696 & 12,500 & 0,136 \\
Warga & 2,15 & 8,333 & 0,258 \\
Pos 1 & 2,28 & 5,556 & 0,410 \\
Pos 2 & 3,204 & 2,222 & 1,442 \\
Air Terjun &
\end{tabular}

Nilai kekayaan jenis burung di Kawasan Air Terjun Tretes, Wonosalam beragam. Pada titik pengamatan air terjun didapatkan nilai kekayaan jenis tertinggi dengan nilai sebesar 8,68 dibandingkan dengan jalur yang lain. Karena jalur ini memiliki beragam tipe vegetasi. Pada titik pengamatan pemukiman warga nilai kekayaan jenis yang terendah yaitu dengan nilai 1,563. Dari data tersebut dapat ditarik kesimpulan sementara bahwa semakin tinggi kekayaan jenisnya semakin besar pula nilai indeks margalef.

\section{Vegetasi Air Terjun}

Kondisi vegetasi hutan hujan yang mudah rusak dan beberapa pohon memiliki sifat meranggas menjadi pendukung adanya sumber daya makanan yang melimpah. Selain itu, hutan hujan juga menjadi habitat yang cukup aman bagi burung sebaran penetap, endemik dan terbatas karena merupakan habitat alami dan tidak banyak aktifitas dari manusia. Habitat burung-burung 
penetap dalam hutan hujan yang digunakan merupakan sebuah bukti bahwa habitat alami inilah yang memberikan daya dukung penting bagi sebagian besar burung-burung di bentang alam Air Terjun Tretes, Wonosalam. Selain itu, hutan hujan juga mendukung keberadaan delapan jenis burung yang dilindungi dalam perdangangan internasional (CITES). Hal ini memperkuat peranan habitat hutan hujan bagi kelangsungan hidup jenis-jenis burung yang dilindungi.

Tabel 4. Daftar Pohon Wilayah Air Terjun Tretes

\begin{tabular}{|c|c|c|}
\hline No & Nama Spesies & $\begin{array}{l}\text { Nama } \\
\text { Indonesia }\end{array}$ \\
\hline 1 & $\begin{array}{l}\text { Swietenia } \\
\text { macrophylla King }\end{array}$ & Mahoni \\
\hline 2 & Coffea arabica $L$. & Kopi \\
\hline 3 & Ceiba petandra & Randu \\
\hline 4 & $\begin{array}{l}\text { Aleurites } \\
\text { moluccana }\end{array}$ & Kemiri \\
\hline 5 & Durio zibethinus & Durian \\
\hline 6 & Ficus variegata & Gondang \\
\hline 7 & Maesopsis eminii & Sobsi \\
\hline 8 & Rhadamnia cinerea & Andong \\
\hline 9 & Eugenia aperculata & Salam \\
\hline 10 & Tectona grandis & Jati \\
\hline 11 & Melia azedarach & Mindi \\
\hline
\end{tabular}

Jenis pohon yang paling banyak terdapat di daerah area penelitian adalah jenis kopi (Coffea arabica L.) dan mahoni (Swietenia macrophylla King.). Tumbuhnya tanaman kopi tegak, bercabang dan dapat mencapai tinggi hingga 12 $\mathrm{m}$. Sedangkan pohon mahoni termasuk dalam pohon besar dengan tinggi pohon hingga 35-40 m dan diameter mencapai $125 \mathrm{~cm}$.Pohon mahoni bisa mengurangi polusi udara sekitar $47 \%-69 \%$ sehingga disebut sebagai pohon pelindung serta filter udara dan daerah tangkapan air. Daundaunnya bertugas menyerap polutan-polutan di sekitarnya. Sebaliknya, dedaunan itu akan melepaskan oksigen $(\mathrm{O} 2)$ yang membuat udara di sekitarnya menjadi segar (Zain, 1992), sehingga pohon mahoni ini bermanfaat besar untuk penduduk sekitar.

Komposisi jenis pohon adalah Swietenia macrophylla King., Coffea arabica L., Ceiba petandra, Aleurites moluccana,Durio zibethinus, Ficus variegata., Maesopsis eminii, Rhadamnia cinerea, Eugenia aperculata, Tectona grandis,dan Melia azedarach dengan rata-rata pohon jaraknya 4,96 $\mathrm{m}$ dan rata-rata pohon tingginya $14,77 \mathrm{~m}$.

\section{Tipe Pakan/Feeding Guild}

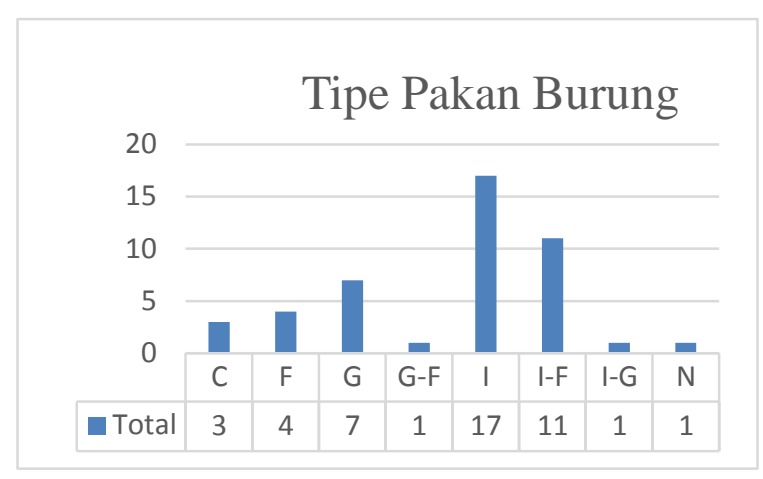

Gambar 3. Grafik Pengelompokkan Burung Berdasarkan Tipe Pakan

Keterangan:

I: Pemakan Serangga (Insektivora), F: Pemakan Buah- Buahan (Frugivora), G: Pemakan BijiBijian (Graminivora), N: Pemakan Nektar (Nektarivora), C: Pemakan Daging (Carinivora)

Komposisi jenis berdasarkan tipe pakan di Air Terjun Tretes, Wonosalam terdapat burung insektivora sebesar 58\% yang mendominasi dibandingkan dengan jenis burung lain. Kondisi habitat di Air Terjun Tretes, Wonosalam dimana vegetasi pohon rapat yang mendominasi menjadikan jenis burung insektivora lebih tinggi prosentase komposisi jenisnya. Vegetasi yang rapat memiliki kelembaban yang sesuai untuk kehidupan serangga sehingga kebutuhan makanan burung insektivora tersedia. Burung Walet Linchi contohnya termasuk dalam burung insektivora yang ditemukan melimpah dan dijumpai di seluruh stasiun penelitian. Faktor alam juga mempengaruhi keragaman variasi dan sifat tumbuhan dalam menghasilkan sumber pakan (buah dan bunga). Variasi ini menunjukkan dinamika spesies setiap tipe habitat.

\section{Suhu dan PH Tanah}

$\mathrm{pH}$ tanah berperan penting dalam ekologi Burung Hutan karena keberadaan dan kepadatan Burung Hutan memiliki ketergantungan pada $\mathrm{pH}$ tanah. Pada lokasi penelitian didapatkan rata $\mathrm{pH} 6$ namun $\mathrm{pH}$ tersebut kurang sesuai dengan kehidupan Burung Hutan. Pengukuran $\mathrm{pH}$ tanah sangat penting dalam ekologi burung hutan karena keberadaan dan kepadatan burung hutan 
sangat bergantung pada $\mathrm{Ph}$ tanah (Suin, 2012). Handayanto \& Hairiah (2009) menjelaskan bahwa sebagian besar burung hutan hidup dengan $\mathrm{pH}$ berkisar 6-7 karena ketersediaan unsur hara yang cukup tinggi. Kondisi $\mathrm{pH}$ tanah yang terlalu asam dan basa dapat menimbulkan kehidupan burung hutan terganggu, tetapi Suin (2012) menjelaskan bahwa terdapat juga burung hutan yang bisa hidup dalam kondisi $\mathrm{pH}$ asam dan dapat dijumpai pula dalam kondisi $\mathrm{pH}$ basah

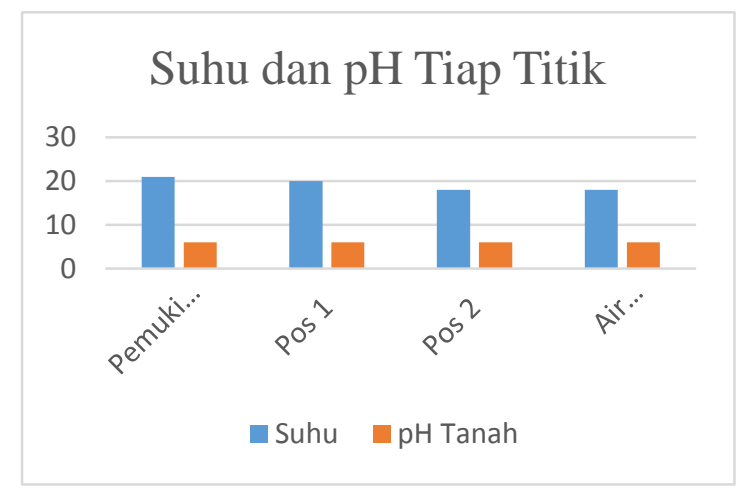

Gambar 4. Grafik Suhu dan PH Tanah

Suhu tanah merupakan faktor fisika tanah yang menentukan tingkat keanekaragaman jenis burung hutan, suhu tanah juga menentukan proses terjadinya dekomposisi bahan organik tanah (Suin, 2012). Didapatkan suhu rata-rata 22oC pada lokasi penelitian diamana suhu tersebut sesuai dengan kehidupan makrofauna tanah. Menurut Handayanto \& Hairiah (2009) menjelaskan bahwa suhu tanah sangat terkait erat dengan kelambaban tanah. Jenis-jenis burung hutan memiliki variasi suhu yang berbeda dalam mempertahankan tubuhnya. Seperti dijelaskan Sukarsono (2009) bahwa fruktuasi 10-20oC dengan rata-rata $15 \mathrm{oC}$ tidak sama pengaruhnya terhadap burung hutan bila di bandingkan dengan lingkungan bersuhu konstan $15 \mathrm{oC}$, laju tersebut menghasilkan pertumbuhan yang lebih cepat pada sebagian burung hutan.

Campbel (2008, hlm.332) mengatakan, Suhu lingkungan merupakan faktor yang paling penting dalam penyebaran organisme karena efeknya terhadap proses-proses biologis. Burung dapat mempertahankan suhu tubuh yang konstan pada $40^{\circ} \mathrm{C}$ dan suhu maximunya $60^{\circ} \mathrm{C}$, selama memiliki air yang cukup. Burung dapat hidup di suhu lingkungan $-40{ }^{\circ} \mathrm{C}$, selama memiliki makanan yang cukup".

\section{Potensi Avitourism}

Potensi pengembangan kawasan pariwisata berbasis konsep aksesibilitas, amenitas, dan atraksi sering disebut 3A. Yang menjadi bagian dari atribut avitourism adalah Aksesibilitas dan amenitas. Atraksi merupakan potensi yang dimiliki di suatu kawasan, dalam hal ini burung sebagai objek avitourism. Burung yang berpotensi menjadi daya tarik adalah burung jenis raptor, endemisitas, burung yang masuk dalam status konservasi tinggi menurut IUCN, CITES, dilindungi pemerintah, burung yang memiliki warna menarik dan suara yang indah.

\section{Kesimpulan}

Jenis burung yang ditemukan di Air Terjun Tretes, Wonosalam sebanyak 45 spesies dengan Nilai kelimpahan jenis burung pada titik pengamatan pemukiman warga dikategorikan umum. Sedangkan kelimpahan jenis burung pada titik pengamatan pos 1 , pos 2 dan air terjun termasuk kategori sering $(2,1-10,0)$.. Kekayaan jenis tertinggi dijumpai di jalur Air Terjun Tretes. Jenis burung didominasi burung insektivora. Hutan hujan juga mendukung keberadaan tiga jenis burung yang dilindungi dalam perdangangan internasional (CITES). Hal ini memperkuat peranan habitat hutan hujan bagi kelangsungan hidup jenis-jenis burung yang dilindungi. Berdasarkan potensi avitourism beberapa jenis memiliki status konservasi tinggi yaitu satu jenis terindeks IUCN Redlist dan satu jenis masuk Appendix II CITES, serta delapan yang dilindungi pemerintah. Air Terjun Tretes sangat potensial untuk kembangkan sebagai kawasan avitourism. Penelitian lebih mendalam dapat dilakukan untuk mengetahui distribusi spasial dan temporal burung di Air Terjun Tretes sehingga avitourism lebih mudah untuk dikembangkan.

\section{Ucapan Terima Kasih}

Penelitian ini dapat terlaksana dengan baik berkat bantuan dari berbagai pihak, oleh sebab itu peneliti mengucapkan terima kasih kepada Penalaran FMIPA yang sudah memberikan kami kesempatan untuk melaksanakan penelitian, Pihak Pengelola Obyek Wisata Air Terjun Tretes, Wonosalam, Ibu Reni Ambarwati, S.Si, M.Sc Selaku Pembimbing, Bapak Dr Sunu Kuntjoro, 
M.Si dan Ibu Dr. Mahanani Tri Asri, M.Si Selaku reviewer, Agus Nurrofik, Afina Aninnas serta teman-teman dan saudara yang membantu penulis dalam menyusun artikel penelitian ini sampai akhir.

\section{Referensi}

Bibby C, Jones M, \& Marsden S (2000) Teknikteknik lapangan survei burung. Bogor, Birdlife Indonesia Programme, pp 119121.

Biggs D, Turpieb J, Fabriciusc C, \& Spenceleyd A (2011) The value of Avitourism for conservation and job creation - an analysis from South Africa. Conservation and Society 9 (1): $80-90$. DOI: $10.4103 / 0972-4923.79198$

Biggs D, Turpieb J, Fabriciusc C, \& Spenceleyd A (2011) The value of Avitourism for conservation and job creation - an analysis from South Africa. Conservation and Society 9 (1): 80-90. DOI: $10.4103 / 0972-4923.79198$

Bismark M (2011) Prosedur Operasi Standar (SOP) untuk survei keragaman jenis pada kawasan konservasi. Pusat Penelitian dan Pengembangan Perubahan Iklim dan

Kebijakan Badan Penelitian dan Pengembangan Kehutanan. Bogor.

Burung Indonesia (2018) Birding guides \& services in Indonesia. http://burungnusantara.org/birdingindonesi a/guides-and-services/. Diakses: 16 Juni 2021.

Burung Indonesia (2017). Infografis Status Burung di Indonesia. diakses pada http://www.burungindonesia.org pada 24 Mei 2021

CITES (2015). Appendices I, II and III [Internet]. [diunduh 2021 May 21]. Tersedia pada: http://www.cites.org.

Cordell, H.K. and N.G. Herbert. (2002). The popularity of birding is still growing. Birding 34: 54-59. https://www.srs.fs.usda.gov/pubs/ja/ja_cor dell002.pdf

Conradie N (2015). Profiling the international avitourist: preferences of avitourists at the British and Dutch birdwatching fairs. African Journal of Hospitality, Tourism and Leisure 4 (1): 1-26. http://www.ajhtl.com/uploads/7/1/6/3/716 3688/article28vol4-1-jan-june-2015.pdf

Diamond JM, Bishop KD, \& van Balen S (1987). Bird Survival in an Isolated Javan Woodland: Island or Mirror. Conservation Biology $1 \quad$ (2): 132-142. https://doi.org/10.1111/j.15231739.1987.tb00022.x

Garnett ST, Ainsworth GB, \& Zander KK (2018). Are we choosing the right flagships? The bird species and traits Australians find most attractive. PloS one 13 (6): 1- 17.

DOI:

https://doi.org/10.1371/journal.pone.01992 $\underline{53}$

Handayanto, E., \& K. Hairiah (2009). Biologi Tanah: Landasan Pengelolaan Tanah. Yogyakarta: Pustaka Adiputra.

Hvengaard, G.T. and P. Dearden. (1998). Linking ecotourism and biodiversity conservation: A case study of Doi Inthanon National Park, Thailand. Singapore Journal of Tropical Geography 19: 193-211. DOI : https://doi.org/10.1111/j.14679493.1998.tb00259.x

IUCN (2012). IUCN Red List Categories and Criteria: Version 3.1. Second edition. Gland, Switzerland and Cambridge, UK: IUCN. pp iv-32

Kementrian Lingkungan Hidup dan Kehutanan (KLHK) (2019). Panduan identifikasi jenis satwa liar dilindungi aves seri Passeriformes (Burung Kicau). Jakarta: Kementrian Lingkungan Hidup dan Kehutanan. Pp 13-17.

Maarel, E.V.D. (2005). Vegetation Ecology. Victoria: Blackwell Publishing. Margalef R 
(1958) Information theory in Ecology. International Journal of General Systems 3: $36-71$

Naidoo, R. and W.L. Adamowicz (2005a). Biodiversity and nature-based tourism at forest reserves in Uganda. Environment and Development Economics 10: 159-178. DOI: $10.1017 / \mathrm{S} 1355770 \mathrm{X} 0400186 \mathrm{X}$

Naidoo, R. and W.L. Adamowicz. (2005b). Economic benefi ts of biodiversity exceed costs of conservation at an African rainforest reserve. Proceedings of the National Academy of Sciences 102: 16712-16716. DOI: https://doi.org/10.1073/pnas.0508036102

Natural Resources Conservation Service (2014). an Equal Opportunity Provider and Employer. 2014.

Odum EP (1991). Dasar - dasar ekologi. Yogyakarta, Gadjah Mada University Press, pp 395-399.

Puhakka L, Salo M, \& Saaksjarvi IE (2011). Bird Diversity, Birdwatching Tourism and Conservation in Peru: A Geographic Analysis. PLoS ONE 6 (11): 1-14.. DOI: https://doi.org/10.1371/journal.pone.00267 $\underline{86}$

Riefani MK, Soendjoto MA, \& Munir AM (2019). Bird species in the cement factory complex of Tarjun, South Kalimantan, Indonesia. Biodiversitas 20 (1): 218-225. DOI:

https://doi.org/10.13057/biodiv/d200125

Rumanasari RD, Saroyo S, \& Katili DY (2017). Biodiversitas burung pada beberapa tipe habitat di kampus Universitas Sam Ratulangi. Jurnal MIPA 6 (1): 43-46 DOI: https://doi.org/10.35799/jm.6.1.2017.1615 $\underline{3}$

Smith, P.L. Wilson, B., Nadolny, C., \& Lang, D. (2000). The Ecological Ro-le of The Native Vegetation of New South Wales. New South Wales: Native Vegetation Advisory
Council.

DOI:

http://dx.doi.org/10.5772/55813

Soemarwoto, Otto (2001). Ekologi, Lingkungan Hidup dan Pembangunan Djambatan. Sukmantoro W, Irham M, Novarino W, Hasudungan F, Kemp N, Muchtar M(2007) Daftar Burung Indonesia no. 2. Bogor, Indonesian Ornithologists'Union, pp 3-4

Suin, Nurdin Muhammad (2012). Ekologi Hewan Tanah. Jakarta: PT Bumi Aksara.

Sukmantoro W, Irham M, Novarino W, Hasudungan F, Kemp N, \& Muchtar M(2007) Daftar Burung Indonesia no. 2. Bogor, Indonesian Ornithologists'Union, pp 3-4

Syafrudin D. (2011). Jurnal Keanekaragaman Jenis Burung Pada beberapa Tipe Habitat Di Tambling Wildlife Nature Conservation (TWNC). Diakses tanggal 12 Juni 2021 pukul 15.20 Wib DOI: https://repository.ipb.ac.id/handle/123456 789/47628? show $=$ full

US Fish and Wildlife Service (2001). Birding in the United States: A demographic and economic analysis. Addendum to the 2001 national survey of fi shing, hunting and wildlife associated recreation. Report 1 2001. US Fish \& Wildlife Service. Washington DC, USA. DOI: https://digitalmedia.fws.gov/digital/collect ion/document/id/291/rec/2

Wisnubudi G. (2009). Penggunaan strata vegetasi oleh burung di Kawasan Wisata Taman Nasional Gunung Halimun-Salak. Jurnal Vis Vitalis. 2(2) : 41-49.

Zain, A. S. (1992). Aspek Pembinaan Kawasan Hutan dan Stratifikasi Hutan Rakyat.Jakarta; Rine Kartika. 
Afnan, MZ et al. (2022). Jurnal Biologi Tropis, 22 (1): 158 - 172 DOI: http://dx.doi.org/10.29303/jbt.v22i1.3152

\section{LAMPIRAN BURUNG AIR TERJUN TRETES, WONOSALAM}

\begin{tabular}{|c|c|c|c|c|c|c|c|c|c|c|}
\hline No & Famili & $\begin{array}{l}\text { Nama } \\
\text { Species }\end{array}$ & Nama Latin & Nama Inggris & $\begin{array}{l}\text { Distribusi } \\
\text { Lokal* }\end{array}$ & $\begin{array}{l}\text { Distribusi } \\
\text { Regional** }\end{array}$ & IUCN*** & $\begin{array}{l}\text { Permen } \\
\text { LHK**** }\end{array}$ & CITES & $\sum$ Individu \\
\hline 1 & Aegithilidae & $\begin{array}{l}\text { Cerecet } \\
\text { Jawa }\end{array}$ & Psaltria exilis & Pygmy Tit & 4 & $\mathrm{~J}$ & LC & $\mathrm{D}$ & $\begin{array}{l}\text { non } \\
\text { apendiks }\end{array}$ & 2 \\
\hline 2 & Aegithinidae & $\begin{array}{l}\text { Cipoh } \\
\text { Kacat }\end{array}$ & Aegthina tiphia & $\begin{array}{l}\text { Common } \\
\text { Iora }\end{array}$ & $1,3,4$ & $\mathrm{~S}, \mathrm{~K}, \mathrm{~J}, \mathrm{~B}$ & $\mathrm{LC}$ & $\mathrm{TD}$ & $\begin{array}{l}\text { non } \\
\text { apendiks }\end{array}$ & 12 \\
\hline 3 & Alcedinidae & $\begin{array}{l}\text { Cekakak } \\
\text { Sungai }\end{array}$ & $\begin{array}{l}\text { Todiramphus } \\
\text { chloris }\end{array}$ & $\begin{array}{l}\text { Collared } \\
\text { kingfisher }\end{array}$ & $1,2,3,4$ & $\mathrm{~S}, \mathrm{~K}, \mathrm{~J}, \mathrm{~B}$ & $\mathrm{LC}$ & $\mathrm{TD}$ & $\begin{array}{l}\text { non } \\
\text { apendiks }\end{array}$ & 10 \\
\hline 4 & Alcedinidae & $\begin{array}{l}\text { Raja } \\
\text { udang } \\
\text { Biru }\end{array}$ & $\begin{array}{l}\text { Alcedo } \\
\text { coerulescens }\end{array}$ & $\begin{array}{l}\text { Cerulean } \\
\text { Kingfisher }\end{array}$ & $1,3,4$ & $\mathrm{~S}, \mathrm{~J}, \mathrm{~B}$ & $\mathrm{LC}$ & TD & $\begin{array}{l}\text { non } \\
\text { apendiks }\end{array}$ & 9 \\
\hline 5 & Apodidae & $\begin{array}{l}\text { Walet } \\
\text { linchi }\end{array}$ & $\begin{array}{l}\text { Collocalia } \\
\text { linchi }\end{array}$ & Cave Swiftlet & $1,2,3,4$ & S,J,B & $\mathrm{LC}$ & $\mathrm{TD}$ & $\begin{array}{l}\text { non } \\
\text { apendiks }\end{array}$ & 100 \\
\hline 6 & Campephagidae & $\begin{array}{l}\text { Sepah } \\
\text { Gunung }\end{array}$ & $\begin{array}{l}\text { Pericrocotus } \\
\text { miniatus }\end{array}$ & $\begin{array}{l}\text { Sunda } \\
\text { Minivet }\end{array}$ & 4 & $\mathrm{~S}, \mathrm{~J}$ & $\mathrm{LC}$ & $\mathrm{TD}$ & $\begin{array}{l}\text { non } \\
\text { apendiks }\end{array}$ & 1 \\
\hline 7 & Choloropsidae & $\begin{array}{l}\text { Cica-daun } \\
\text { Besar }\end{array}$ & $\begin{array}{l}\text { Chloropsis } \\
\text { sonnerati }\end{array}$ & $\begin{array}{l}\text { Greater } \\
\text { Green } \\
\text { Leafbird }\end{array}$ & 4 & $\mathrm{~S}, \mathrm{~K}, \mathrm{~J}, \mathrm{~B}$ & $\mathrm{LC}$ & $\mathrm{TD}$ & $\begin{array}{l}\text { non } \\
\text { apendiks }\end{array}$ & 1 \\
\hline 8 & Choloropsidae & $\begin{array}{l}\text { Cica- } \\
\text { Rante }\end{array}$ & $\begin{array}{l}\text { Pycnonotus } \\
\text { bimaculatus }\end{array}$ & $\begin{array}{l}\text { Orange- } \\
\text { spotted } \\
\text { bulbul }\end{array}$ & 4 & $\mathrm{~S}, \mathrm{~J}$ & LC & $\mathrm{TD}$ & $\begin{array}{l}\text { non } \\
\text { apendiks }\end{array}$ & 1 \\
\hline
\end{tabular}


Afnan, MZ et al. (2022). Jurnal Biologi Tropis, 22 (1): 158 - 172 DOI: http://dx.doi.org/10.29303/jbt.v22i1.3152

\begin{tabular}{|c|c|c|c|c|c|c|c|c|c|}
\hline 9 & Columbidae & $\begin{array}{l}\text { Punai } \\
\text { Gading }\end{array}$ & Treron vernans & $\begin{array}{l}\text { Pink-necked } \\
\text { Greean- } \\
\text { pigeon }\end{array}$ & 4 & $\mathrm{~S}, \mathrm{~K}, \mathrm{~J}, \mathrm{~B}$ & $\mathrm{LC}$ & $\mathrm{TD}$ & $\begin{array}{l}\text { non } \\
\text { apendiks }\end{array}$ \\
\hline 10 & Columbidae & $\begin{array}{l}\text { Punai } \\
\text { Pengantin }\end{array}$ & $\begin{array}{l}\text { Treron } \\
\text { griseicauda }\end{array}$ & $\begin{array}{l}\text { Grey- } \\
\text { cheeked } \\
\text { Green-pigeon }\end{array}$ & 4 & $\mathrm{~J}, \mathrm{~B}$ & $\mathrm{LC}$ & $\mathrm{TD}$ & $\begin{array}{l}\text { non } \\
\text { apendiks }\end{array}$ \\
\hline 11 & Columbidae & $\begin{array}{l}\text { Pergam } \\
\text { Gunung }\end{array}$ & Ducula badia & $\begin{array}{l}\text { Mountain } \\
\text { Imperial- } \\
\text { pigeon }\end{array}$ & 3,4 & $\mathrm{~S}, \mathrm{~K}, \mathrm{~J}$ & $\mathrm{LC}$ & $\mathrm{TD}$ & $\begin{array}{l}\text { non } \\
\text { apendiks }\end{array}$ \\
\hline 12 & Columbidae & $\begin{array}{l}\text { Tekukur } \\
\text { Biasa }\end{array}$ & $\begin{array}{l}\text { Spilopelia } \\
\text { chinensis }\end{array}$ & $\begin{array}{l}\text { Eastern } \\
\text { Spotted Dove }\end{array}$ & $1,2,4$ & $\mathrm{~S}, \mathrm{~K}, \mathrm{~J}, \mathrm{~B}$ & $\mathrm{LC}$ & $\mathrm{TD}$ & $\begin{array}{l}\text { non } \\
\text { apendiks }\end{array}$ \\
\hline 13 & Columbidae & $\begin{array}{l}\text { Perkutut } \\
\text { Jawa }\end{array}$ & Geopelia striata & Zebra Dove & $1,2,4$ & $\mathrm{~S}, \mathrm{~K}, \mathrm{~J}, \mathrm{~B}$ & $\mathrm{LC}$ & TD & $\begin{array}{l}\text { non } \\
\text { apendiks }\end{array}$ \\
\hline 14 & Columbidae & $\begin{array}{l}\text { Delimukan } \\
\text { Zamrud }\end{array}$ & $\begin{array}{l}\text { Chalcophaps } \\
\text { indica }\end{array}$ & $\begin{array}{l}\text { Grey-capped } \\
\text { Emerald } \\
\text { Dove }\end{array}$ & 4 & $\mathrm{~S}, \mathrm{~K}, \mathrm{~J}, \mathrm{~B}$ & $\mathrm{LC}$ & $\mathrm{TD}$ & $\begin{array}{l}\text { non } \\
\text { apendiks }\end{array}$ \\
\hline 15 & Columbidae & $\begin{array}{l}\text { Walik } \\
\text { Kembang }\end{array}$ & $\begin{array}{l}\text { Ptilinopus } \\
\text { melanospilus }\end{array}$ & $\begin{array}{l}\text { Black-naped } \\
\text { Fruit-dove }\end{array}$ & 3,4 & $\mathrm{~K}, \mathrm{~J}, \mathrm{~B}$ & $\mathrm{LC}$ & $\mathrm{TD}$ & $\begin{array}{l}\text { non } \\
\text { apendiks }\end{array}$ \\
\hline 16 & Columbidae & $\begin{array}{l}\text { Walik } \\
\text { Kepala - } \\
\text { Ungu }\end{array}$ & $\begin{array}{l}\text { Ptilinopus } \\
\text { porphyreus }\end{array}$ & $\begin{array}{l}\text { Pink-headed } \\
\text { Fruit-dove }\end{array}$ & 3,4 & $\mathrm{~S}, \mathrm{~J}$ & $\mathrm{LC}$ & $\mathrm{TD}$ & $\begin{array}{l}\text { non } \\
\text { apendiks }\end{array}$ \\
\hline 17 & Cuculidae & $\begin{array}{l}\text { Bubut } \\
\text { Jawa }\end{array}$ & $\begin{array}{l}\text { Centropus } \\
\text { nigrorufus }\end{array}$ & Javan Coucal & 3,4 & $\mathrm{~J}$ & VU & $\mathrm{D}$ & $\begin{array}{l}\text { non } \\
\text { apendiks }\end{array}$ \\
\hline
\end{tabular}


Afnan, MZ et al. (2022). Jurnal Biologi Tropis, 22 (1): 158 - 172 DOI: http://dx.doi.org/10.29303/jbt.v22i1.3152

\begin{tabular}{|c|c|c|c|c|c|c|c|c|c|c|}
\hline 18 & Dicaeidae & $\begin{array}{l}\text { Cabai } \\
\text { Jawa }\end{array}$ & $\begin{array}{l}\text { Dicaeum } \\
\text { trochileum }\end{array}$ & $\begin{array}{l}\text { Scarled- } \\
\text { headed } \\
\text { Flowerpecker }\end{array}$ & $2,3,4$ & S,K,J,B & $\mathrm{LC}$ & $\mathrm{TD}$ & $\begin{array}{l}\text { non } \\
\text { apendiks }\end{array}$ & 32 \\
\hline 19 & Dicaeidae & $\begin{array}{l}\text { Cabai } \\
\text { Gunung }\end{array}$ & $\begin{array}{l}\text { Dicaeum } \\
\text { sanguinolentum }\end{array}$ & $\begin{array}{l}\text { Blood- } \\
\text { breasted } \\
\text { Flowerpecker }\end{array}$ & $2,3,4$ & $\mathrm{~J}, \mathrm{~B}$ & $\mathrm{LC}$ & $\mathrm{TD}$ & $\begin{array}{l}\text { non } \\
\text { apendiks }\end{array}$ & 15 \\
\hline 20 & Dicaeidae & $\begin{array}{l}\text { Cabai } \\
\text { Gunung }\end{array}$ & $\begin{array}{l}\text { Dicaeum } \\
\text { sanguinolentum }\end{array}$ & $\begin{array}{l}\text { Blood- } \\
\text { breasted } \\
\text { Flowerpecker }\end{array}$ & 4 & $\mathrm{~J}, \mathrm{~B}$ & $\mathrm{LC}$ & $\mathrm{TD}$ & $\begin{array}{l}\text { non } \\
\text { apendiks }\end{array}$ & 1 \\
\hline 21 & Estrildidae & $\begin{array}{l}\text { Bondol } \\
\text { Jawa }\end{array}$ & $\begin{array}{l}\text { Lonchura } \\
\text { 'leucogastroides }\end{array}$ & Javan Munia & $1,2,4$ & $\mathrm{~S}, \mathrm{~J}, \mathrm{~B}$ & $\mathrm{LC}$ & $\mathrm{TD}$ & $\begin{array}{l}\text { non } \\
\text { apendiks }\end{array}$ & 40 \\
\hline 22 & Estrildidae & $\begin{array}{l}\text { Bondol } \\
\text { Peking }\end{array}$ & $\begin{array}{l}\text { Lonchura } \\
\text { punctulata }\end{array}$ & $\begin{array}{l}\text { Scaly- } \\
\text { breasted } \\
\text { Munia }\end{array}$ & 2,4 & S,K,J,B & $\mathrm{LC}$ & $\mathrm{TD}$ & $\begin{array}{l}\text { non } \\
\text { apendiks }\end{array}$ & 24 \\
\hline 23 & Estrildidae & $\begin{array}{l}\text { Bondol } \\
\text { Haji }\end{array}$ & Lonchura maja & $\begin{array}{l}\text { White- } \\
\text { headed } \\
\text { Munia }\end{array}$ & 4 & $\mathrm{~S}, \mathrm{~J}, \mathrm{~B}$ & $\mathrm{LC}$ & $\mathrm{TD}$ & $\begin{array}{l}\text { non } \\
\text { apendiks }\end{array}$ & 1 \\
\hline 24 & Falconidae & $\begin{array}{l}\text { Alap-alap } \\
\text { Kawah }\end{array}$ & $\begin{array}{l}\text { Falco } \\
\text { peregrinus }\end{array}$ & $\begin{array}{l}\text { Peregrine } \\
\text { Falcon }\end{array}$ & 4 & $\mathrm{~K}, \mathrm{~J}, \mathrm{~B}$ & $\mathrm{LC}$ & $\mathrm{D}$ & I & 1 \\
\hline 25 & Falconidae & $\begin{array}{l}\text { Alap-alap } \\
\text { Sapi }\end{array}$ & $\begin{array}{l}\text { Falco } \\
\text { muloccensis }\end{array}$ & $\begin{array}{l}\text { Spotted } \\
\text { Kestrel }\end{array}$ & 4 & $\mathrm{~J}, \mathrm{~B}$ & $\mathrm{LC}$ & $\mathrm{D}$ & II & 1 \\
\hline
\end{tabular}


Afnan, MZ et al. (2022). Jurnal Biologi Tropis, 22 (1): 158 - 172 DOI: http://dx.doi.org/10.29303/jbt.v22i1.3152

\begin{tabular}{|c|c|c|c|c|c|c|c|c|c|}
\hline 26 & Muscicapidae & $\begin{array}{l}\text { Kucica } \\
\text { Hutan }\end{array}$ & $\begin{array}{l}\text { Copsychus } \\
\text { malabaricus }\end{array}$ & $\begin{array}{l}\text { White- } \\
\text { rumped } \\
\text { Shama }\end{array}$ & 3,4 & $\mathrm{~S}, \mathrm{~J}$ & $\mathrm{LC}$ & $\mathrm{D}$ & $\begin{array}{l}\text { non } \\
\text { apendiks }\end{array}$ \\
\hline 27 & Muscicapidae & $\begin{array}{l}\text { Berkecet } \\
\text { biru-tua }\end{array}$ & Myiomela diana & $\begin{array}{l}\text { Sunda Blue } \\
\text { Robin }\end{array}$ & 4 & $\mathrm{~S}, \mathrm{~J}$ & $\mathrm{LC}$ & $\mathrm{D}$ & $\begin{array}{l}\text { non } \\
\text { apendiks }\end{array}$ \\
\hline 28 & Muscicapidae & $\begin{array}{l}\text { Meninting } \\
\text { Besar }\end{array}$ & $\begin{array}{l}\text { Enicurus } \\
\text { leschenaulti }\end{array}$ & $\begin{array}{l}\text { White } \\
\text { crowned } \\
\text { Forktail }\end{array}$ & 4 & $\mathrm{~S}, \mathrm{~K}, \mathrm{~J}, \mathrm{~B}$ & $\mathrm{LC}$ & TD & $\begin{array}{l}\text { non } \\
\text { apendiks }\end{array}$ \\
\hline 29 & Muscicapidae & $\begin{array}{l}\text { Sikatan } \\
\text { Biru Putih }\end{array}$ & $\begin{array}{l}\text { Cyanoptila } \\
\text { cyanomelana }\end{array}$ & $\begin{array}{l}\text { Blue-and- } \\
\text { white } \\
\text { Flycatcher }\end{array}$ & 4 & $\mathrm{~S}, \mathrm{~K}, \mathrm{~J}$ & $\mathrm{LC}$ & TD & $\begin{array}{l}\text { non } \\
\text { apendiks }\end{array}$ \\
\hline 30 & Muscicapidae & $\begin{array}{l}\text { Sikatan } \\
\text { Cacing }\end{array}$ & $\begin{array}{l}\text { Cyornis } \\
\text { banyunas }\end{array}$ & $\begin{array}{l}\text { Hill Blue- } \\
\text { flycatcher }\end{array}$ & 4 & $\mathrm{~K}, \mathrm{~J}$ & $\mathrm{LC}$ & TD & $\begin{array}{l}\text { non } \\
\text { apendiks }\end{array}$ \\
\hline 31 & Nectariniidae & $\begin{array}{l}\text { Burung } \\
\text { Madu } \\
\text { Sriganti }\end{array}$ & $\begin{array}{l}\text { Cinnyris } \\
\text { jugularis }\end{array}$ & $\begin{array}{l}\text { Olive-backed } \\
\text { Sunbird }\end{array}$ & 3,4 & $\mathrm{~S}, \mathrm{~K}, \mathrm{~J}, \mathrm{~B}$ & $\mathrm{LC}$ & TD & $\begin{array}{l}\text { non } \\
\text { apendiks }\end{array}$ \\
\hline 32 & Phasianidae & $\begin{array}{l}\text { Ayam } \\
\text { Hutan } \\
\text { Merah }\end{array}$ & Gallus gallus & $\begin{array}{l}\text { Red } \\
\text { Junglefowl }\end{array}$ & 3,4 & $\mathrm{~S}, \mathrm{~J}, \mathrm{~B}$ & $\mathrm{LC}$ & $\mathrm{TD}$ & $\begin{array}{l}\text { non } \\
\text { apendiks }\end{array}$ \\
\hline 33 & Picidae & $\begin{array}{l}\text { Caladi } \\
\text { Ulam }\end{array}$ & $\begin{array}{l}\text { Dendrocopos } \\
\text { analis }\end{array}$ & $\begin{array}{l}\text { Freckle- } \\
\text { breasted } \\
\text { Woodpecker }\end{array}$ & 3,4 & S,J,B & $\mathrm{LC}$ & TD & $\begin{array}{l}\text { non } \\
\text { apendiks }\end{array}$ \\
\hline 34 & Picidae & $\begin{array}{l}\text { Caladi } \\
\text { Tilik }\end{array}$ & $\begin{array}{l}\text { Picoides } \\
\text { moluccensis }\end{array}$ & $\begin{array}{l}\text { Sunda } \\
\text { pygmy } \\
\text { Woodpecker }\end{array}$ & 3,4 & $\mathrm{~S}, \mathrm{~K}, \mathrm{~J}, \mathrm{~B}$ & LC & $\mathrm{TD}$ & $\begin{array}{l}\text { non } \\
\text { apendiks }\end{array}$ \\
\hline
\end{tabular}


Afnan, MZ et al. (2022). Jurnal Biologi Tropis, 22 (1): 158 - 172 DOI: http://dx.doi.org/10.29303/jbt.v22i1.3152

\begin{tabular}{|c|c|c|c|c|c|c|c|c|c|c|}
\hline 35 & Psittacidae & $\begin{array}{l}\text { Serindit } \\
\text { Jawa }\end{array}$ & $\begin{array}{l}\text { Loriculus } \\
\text { pusillus }\end{array}$ & $\begin{array}{l}\text { Yellow- } \\
\text { throated } \\
\text { Hanging- } \\
\text { parrot }\end{array}$ & 4 & $\mathrm{~J}, \mathrm{~B}$ & NT & $\mathrm{D}$ & II & 3 \\
\hline 36 & Pycnonotidae & $\begin{array}{l}\text { Brinji } \\
\text { Gunung } \\
\text { Jawa }\end{array}$ & Ixos virescens & Sunda Bulbul & 4 & $\mathrm{~S}, \mathrm{~J}$ & $\mathrm{LC}$ & $\mathrm{TD}$ & $\begin{array}{l}\text { non } \\
\text { apendiks }\end{array}$ & 2 \\
\hline 37 & Pycnonotidae & $\begin{array}{l}\text { Cucak } \\
\text { Kutilang }\end{array}$ & $\begin{array}{l}\text { Pycnonotus } \\
\text { aurigaster }\end{array}$ & $\begin{array}{l}\text { Sooty-headed } \\
\text { Bulbul }\end{array}$ & $2,3,4$ & $\mathrm{~S}, \mathrm{~K}, \mathrm{~J}, \mathrm{~B}$ & $\mathrm{LC}$ & $\mathrm{TD}$ & $\begin{array}{l}\text { non } \\
\text { apendiks }\end{array}$ & 39 \\
\hline 38 & Pycnonotidae & $\begin{array}{l}\text { Merbah } \\
\text { Cerukcuk }\end{array}$ & $\begin{array}{l}\text { Pycnonotus } \\
\text { goiavier }\end{array}$ & $\begin{array}{l}\text { Yellow- } \\
\text { vented } \\
\text { Bulbul }\end{array}$ & $1,2,3,4$ & $\mathrm{~S}, \mathrm{~K}, \mathrm{~J}, \mathrm{~B}$ & $\mathrm{LC}$ & $\mathrm{TD}$ & $\begin{array}{l}\text { non } \\
\text { apendiks }\end{array}$ & 64 \\
\hline 39 & Rhipiduridae & $\begin{array}{l}\text { Kipasan } \\
\text { Belang }\end{array}$ & $\begin{array}{l}\text { Rhipidura } \\
\text { javanica }\end{array}$ & $\begin{array}{l}\text { Sunda Pied } \\
\text { Fantail }\end{array}$ & 4 & $\mathrm{~S}, \mathrm{~K}, \mathrm{~J}, \mathrm{~B}$ & $\mathrm{LC}$ & $\mathrm{D}$ & $\begin{array}{l}\text { non } \\
\text { apendiks }\end{array}$ & 1 \\
\hline 40 & Scotocercidae & $\begin{array}{l}\text { Cinenen } \\
\text { Gunung }\end{array}$ & $\begin{array}{l}\text { Phyllerates } \\
\text { cucullatus }\end{array}$ & $\begin{array}{l}\text { Mountain } \\
\text { Tailorbird }\end{array}$ & 4 & $\mathrm{~J}, \mathrm{~B}$ & $\mathrm{LC}$ & $\mathrm{TD}$ & $\begin{array}{l}\text { non } \\
\text { apendiks }\end{array}$ & 1 \\
\hline 41 & Timaliidae & $\begin{array}{l}\text { Tepus } \\
\text { Leher } \\
\text { Putih }\end{array}$ & $\begin{array}{l}\text { Stachyris } \\
\text { thoracica }\end{array}$ & $\begin{array}{l}\text { White-bibbed } \\
\text { Babbler }\end{array}$ & 4 & $\mathrm{~S}, \mathrm{~J}$ & $\mathrm{LC}$ & $\mathrm{TD}$ & $\begin{array}{l}\text { non } \\
\text { apendiks }\end{array}$ & 1 \\
\hline 42 & Turdidae & $\begin{array}{l}\text { Anis } \\
\text { Hutan }\end{array}$ & $\begin{array}{l}\text { Zoothera } \\
\text { andremedae }\end{array}$ & Sunda Thrust & 4 & S,J,B & $\mathrm{LC}$ & $\mathrm{TD}$ & $\begin{array}{l}\text { non } \\
\text { apendiks }\end{array}$ & 3 \\
\hline 43 & Vireonidae & Ciu Jawa & $\begin{array}{l}\text { Chloropsis } \\
\text { kinabaluensis }\end{array}$ & $\begin{array}{l}\text { Bornean } \\
\text { Leafbird }\end{array}$ & 4 & $\mathrm{~S}, \mathrm{~K}, \mathrm{~J}$ & $\mathrm{LC}$ & $\mathrm{TD}$ & $\begin{array}{l}\text { non } \\
\text { apendiks }\end{array}$ & 1 \\
\hline
\end{tabular}


Afnan, MZ et al. (2022). Jurnal Biologi Tropis, 22 (1): $158-172$ DOI: http://dx.doi.org/10.29303/jbt.v22i1.3152

\begin{tabular}{|c|c|c|c|c|c|c|c|c|c|}
\hline 44 Zosteropidae & $\begin{array}{l}\text { Kacamata } \\
\text { Biasa }\end{array}$ & $\begin{array}{l}\text { Zosterops } \\
\text { melanurus }\end{array}$ & $\begin{array}{l}\text { Sangkar } \\
\text { White eye }\end{array}$ & $2,3,4$ & $\mathrm{~J}, \mathrm{~B}$ & VU & TD & $\begin{array}{l}\text { non } \\
\text { apendiks }\end{array}$ & 5 \\
\hline Zosteropidae & $\begin{array}{l}\text { Kacamata } \\
\text { Jawa }\end{array}$ & Zosterops flavus & $\begin{array}{l}\text { Javan White- } \\
\text { eye }\end{array}$ & $2,3,4$ & $\mathrm{~K}, \mathrm{~J}$ & $\mathrm{EN}$ & $\mathrm{D}$ & $\begin{array}{l}\text { non } \\
\text { apendiks }\end{array}$ & 4 \\
\hline
\end{tabular}

\section{Keterangan :}

*Distribusi lokal berdasarkan lokasi pengamatan: $1=$ Pemukiman Warga, $2=\operatorname{Pos} 1,3=$ Pos 2, $4=$ Air Terjun Tretes.

**Distribusi regional berdasarkan Mackinnon, $\mathrm{S}=$ Sumatra, $\mathrm{J}=\mathrm{Jawa}, \mathrm{K}=$ Kalimantan, $\mathrm{B}=\mathrm{Bali}$

*** IUCN Redlist tahun 2012, , LC = Least Concern, NT = Near Threatened, VU = Vulnarable, EN = Endangered

****Peraturan Menteri Lingkungan Hidup dan Kehutanan Republik Indonesia Nomor 106 tahun 2018 tentang Jenis Tumbuhan dan Satwa Yang Dilindungi, $\mathrm{D}=$ Dilindungi, $\mathrm{TD}=$ Tidak Dilindungi 